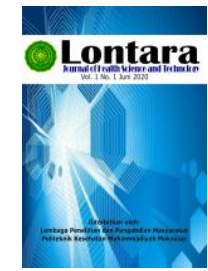

Lontara

Journal of Health Science and Technology

http://jurnal.poltekkesmu.online/lontarariset

Vol 1, No. 2, December 2020, pp 125-135

p-ISSN:0000-0000 dan e-ISSN: 2721-6179

DOI:https://doi.org/

\title{
Analisa Keakuratan Kadar Glukosa Darah Menggunakan Clarke-Error Grid Analisis pada Alat Ukur Non-invasive menggunakan Sensor Photoacoustic
}

\author{
Usman Umar', Risnawaty Alyah'2, Imran Amin ${ }^{3}$ \\ 1,3Teknologi Elektro-medis, Politeknik Kesehatan Muhammadiyah Makassar \\ ${ }^{2}$ Teknik Elektro Universitas Sawerigading Makassar \\ Email: usmanmr4@gmail.com
}

\section{Artikel info}

Artikel history:

Received;03-10-2020

Revised:20-11-2020

Accepted;07-12-2020

Keyword:

Glucose, Non-invasive, sensor, photoacoustic, Clarke

Kata Kunci:

Glukosa, Non-invasive, sensor, fotoakustik, Clarke
Abstract. Blood glucose is a very important element in the human body, but if it is deficient or excessive, it can cause chronic disease that can lead to death. To prevent this, it is necessary to monitor cholesterol and blood glucose levels regularly, at this time the tool for measuring blood glucose levels is still an invasive method by taking a blood sample at the fingertip by injuring it. This study aims to develop a noninvasive blood glucose measuring device using a Photoacoustic Spectroscopy sensor in the range of values from a laser pulse source $(\lambda=650 \mathrm{~nm})$ which can detect glucose signals in the blood. The method of developing this research is by designing a non-invasive measuring instrument and measuring blood glucose levels in male and female participants to create a linearity equation between blood glucose levels and the output voltage from the sensor, then mathematically obtained a polynominal equation to convert the voltage to values. blood glucose level. Validation of measuring instruments designed by comparing invasive measuring instruments as a reference, using the Clarke EGA to determine accuracy based on the classification of values of blood glucose and blood cholesterol levels based on reference. The results of the Clarke EGA analysis show that all measurement data is in Zone A so that the measuring instrument with a photoacoustic sensor can be accepted.

Abstrak. Glukosa darah merupakan unsur yang sangat penting dalam tubuh manusia, namun jika kekurangan atau berlebihan dapat meyebabkan timbulnya penyakit kronis yang dapat mengakibatkan kematian. Untuk mencegah hal tersebut perlu dilakukan pemantauan kadar kolesterol dan glukosa darah secara berkala, pada saat ini alat untuk mengukur kadar glukosa darah masih dengan metode invasive dengan mengambil sampel darah pada ujung jari dengan cara melukai. Penelitian ini bertujuan untuk mengembangkan alat ukur glukosa darah sistem non-invasif menggunakan sensor Spektroskopi Fotoakustik dalam kisaran nilai dari sumber denyut laser $(\lambda=$ $650 \mathrm{~nm}$ ) yang dapat mendeteksi sinyal glukosa dalam darah. 
Metode pengembangan penelitian ini dengan mendesain alat ukur non-invasive dan melakukan pengukuran kadar glukosa darah pada partisipan laki laki dan wanita untuk membuat persamaan linearitas antara kadar glukosa darah dengan tegangan out put dari sensor, kemudaian secara matematika di peroleh persamaan polynominal untuk mengkonversi tegangan ke nilai kadar glukosa darah. Validasi alat ukur yang didesain dengan membandingkan alat ukur invasive sebagai referensi, menggunakan Clarke EGA untuk menentukan keakuratan berdasarkan klasifikasi nilai kadar glukosa darah dan kolesterol darah berdasarkan referensi. Hasil Analisa Clarke EGA menunjukkan bahwa semua data pengukuran masuk Zona A sehingga alat ukur dengan sensor photoakoustik dapat diterima.

Coresponden author:

Email: usmanmr4@gmail.com

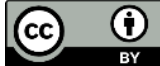

artikel dengan akses terbuka dibawah lisensi CC BY -4.0

\section{PENDAHULUAN}

Glukosa darah yang berlebihan dapat menyebabkan penyakit diabetes melitus (DM). Diabetes melitus merupakan salah satu penyakit kronis serius dimana terjadi pada gangguan metabolik menahun yang diakibatkan oleh pankareas tidak memproduksi insulin yang cukup atau tubuh tidak dapat menggunakan insulin secara efektif yang diproduksi oleh tubuh. Insulin adalah hormon yang mengatur keseimbangan gula dalam darah, mengakibatkan terjadinya peningkatan konsentrasi glukosa dalam darah (hiperglikemia)(WHO, 2016). Beban global penyakit kronis dan tidak menular sebagian besar adalah penyakit jantung, stroke, kanker, penyakit pernafasan kronis, dan diabetes meningkat dengan cepat dan akan memiliki konsekuensi sosial, ekonomi, dan kesehatan yang signifikan kecuali jika segera ditangani.(Riley et al., 2016). Secara global, pada tahun 2014 diperkirakan 422 juta orang dewasa, hidup dengan diabetes. Diabetes menyebabkan 1,5 juta kematian dan dengan meningkatnya glukosa darah yang juga ikut meningkatkan risiko penyakit kardiovaskular dan lainnya, sekitar $43 \%$ dari 3,7 juta sebelum usia 70 tahun. pada negara yang berpenghasilan rendah dan menengah daripada di negara berpenghasilan tinggi. International Diabetes Federation (IDF) menempatkan Indonesia (dengan total 8,5 juta pasien diabetes) sebagai negara dengan populasi diabetes tertinggi ketujuh, menyusul China, India, Amerika Serikat, Brasil, Federasi Rusia, Meksiko, dan Bangladesh. Indonesia dianggap sebagai negara dengan populasi penderita diabetes tertinggi di Asia Tenggara.(Riley et al., 2016). Interval ketidakpastian sekitar perkiraan global orang dewasa dengan diabetes diperkirakan berkisar antara 7,2\% sampai 11,4\% [339-536 juta]. (International Diabetes Federation, 2017). Menurut Riset Kesehatan Dasar (Riskesdas) tahun 2007 dan 2013, PTM menunjukkan adanya kecenderungan semakin meningkat dari waktu ke waktu, tampak kecenderungan peningkatan prevalensi PTM seperti diabetes, hipertensi, stroke, dan penyakit sendi/rematik/encok. Prevalensi di perkotaan sedikit lebih 
Analisa Keakuratan Kadar Glukosa Darah Menggunakan Clarke-Error Grid Analisis pada Alat Ukur Non-invasive menggunakan Sensor Photoacoustic

(Usman Umar, Risnawaty Alyah, Imran Amin)

tinggi $(31,7 \%)$ dibandingkan dengan perdesaan $(30,2 \%)$. Prevalensi semakin meningkat seiring dengan pertambahan umur.(Kemenkes, 2016)

Penelitian yang pernah dilakukan sebelumnya dan mempunyai kaitan dengan topik penelitian yang dilakukan oleh penulis antara lain; penelitan dengan desain sensor pemantau glukosa darah noninvasif yang kontinyu, sensor yang terdiri dari dua resonator cincin split dan dipisahkan secara spasial, di mana seseorang berinteraksi dengan perubahan tingkat glukosa sampel yang diuji sementara cincin lainnya digunakan sebagai referensi. Hasil pengujian menunjukkan interferensi, terjadinya perubahan respon sensor yang didominasi oleh perubahan tingkat glukosa untuk konsentrasi yang relevan dengan darah, dan efek interferensi dapat diabaikan (Choi et.al., 2015). Penelitian untuk melakukan pemantauan glukosa darah noninvasive dengan gelombang frekuensi terahertz. Metode dengan melakukan pengukuran pada enam sukarelawan dengan konsentrasi glukosa darah normal dan dalam keadaan sehat untuk mengambil standar sebagai pembanding (Cherkasova, et.al, 2016). Pengujian glukosa pada okular memiliki potensi besar untuk diagnosis diabetes melitus dengan noninvasif. Memonitor kadar glukosa melalui lensa kontak bisa terbukti lebih mudah dan lebih komprehensif daripada teknik yang umum mengambil sampel darah dengan menusuk jari tangan (Ascaso, 2016). Studi tentang teknik noninvasive untuk menentukan tingkat glukosa dalam tubuh manusia berbasis spektroskopi. dengan optical sensor jenis Spektroskopi Near Infrared Transmisi. (Haxha \& Jhoja, 2016).

Pasien penderita diabetes jika mematuhi diet, olahraga, pengobatan dan melakukan pengukuran kadar glukosa darah yang teratur, mereka dapat mempertahankan kesehatannya, dan menyebabkan kehidupan yang relatif normal. Alat ukur sederhana, murah, handal tersedia, dan bisa melakukan pengukuran sendiri dan teratur dapat membantu pasien dan tidak perlu mendatangi klinik kesehatan, puskesmas dan rumah sakit. Ada tiga metode mengukur glukosa darah yaitu dengan invasive, minimalis invasive dan non invasive

Pengukuran dengan teknik non-invasive yang dikembangkan dengan menggunakan metode Foto-akustik sebagai pengukuran efek energi elektromagnetik yang diserap (terutama cahaya) pada materi dengan cara deteksi akustik. Energi yang diserap dari cahaya diubah menjadi energi kinetik dengan proses pertukaran energi, menghasilkan pemanasan lokal sehingga menimbulkan gelombang. Proses foto-akustik menyebabkan konversi energi optik menjadi energi akustik dengan konversi energi multistage. Fraksi energi optik yang diserap ditentukan oleh koefisien penyerapan optik pulsa fotoakustik dari tekanan gelombang terisolasi, umumnya, amplitudo dari pulsa foto-akustik yang terdeteksi digunakan untuk analisis dan berbanding lurus dengan energi yang diserap (Chen et al., 2017).

Penyerapan cahaya oleh jaringan menyebabkan pemanasan lokal, menimbulkan ekspansi dan kontraksi berikutnya, sehingga terjadi sinyal PA. Karena komposisi darah cukup kompleks dan memiliki berbagai komponen, maka panjang gelombang harus dipilih dengan cermat. 
Pengukuran kadar kolesterol dan glukosa saat ini masih menggunakan cara invasive yang menggunakan sampel darah untuk strip alat ukur, sampel darah diambil dengan menusuk pada ujung jari dan menyakitkan. Alat ukur invasive yang ada saat ini dapat mengukur tiga komponen darah antara lain glukosa, kolesterol dan asam urat darah seperti Easy Touch GCU, Nesc Multicheck, Autocheck dan Accu-Check. Perkembangan teknologi saat ini memungkinkan pemantauan total kolesterol dan glukosa tanpa sampel darah, tetapi dengan sensor yang dipasang pada salah satu bagian tubuh. Pada penelitian ini mengajukan pengembangan alat monitoring untuk kadar glukosa dalam darah dengan penerapan sensor Photoacoustic menggunakan LED dan Photodioda, yang bertujuan memudahkan penderita diabetes melakukan pemantauan secara rutin.

\section{METODE DAN BAHAN}

Sistem yang dirancang dikembangkan dan disimulasikan untuk tujuan mengukur konsentrasi glukosa menggunakan Photo-Acoustic.

Untuk pembangkit sinyal foto-akustik, sampel diiradiasi dengan modulasi amplitudo atau cahaya pulsasi. Molekul yang ada dalam sampel menyerap radiasi dari bagian karakteristik spektrum dan mengubah energi optik yang masuk menjadi pemanasan berkala sampel melalui proses relaksasi non-radiasi. Ini mengarah pada ekspansi volumetrik termodulasi dan ke propagasi gelombang termal dan akustik di dalam sampel. Gelombang akustik dapat dideteksi baik dengan mikrofon dalam gas kopling dalam sel foto-akustik yang ditempatkan pada permukaan sampel atau dengan transduser piezoelektrik yang bersentuhan langsung dengan permukaan sampel. Mekanisme pembangkitan sinyal PA digambarkan pada blok diagram berikut:

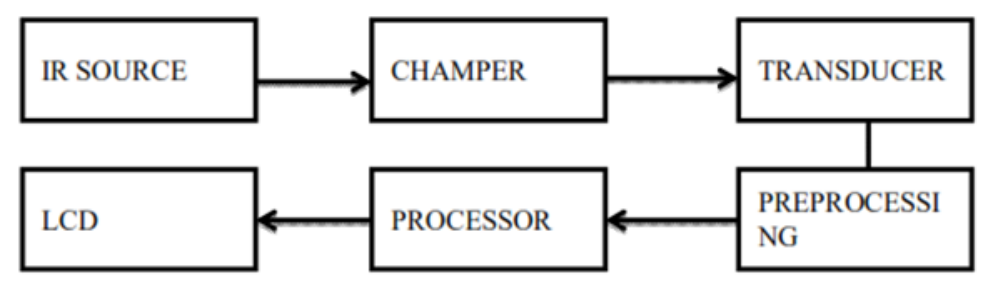

Gambar 1. Blok diagram Photoacoustik

Pada blok diagram tersebut terdapat beberapa komponen yang digunakan antara lain

1. IR Source, 650nm Laser sensor Module 6mm 5V 5mW Red Laser Dot Diode Copper Head

2. Measurement Champer. Ini adalah bagian dari komponen sirkuit yang digunakan dan terbuat dari (Teflon). Itu terjadi untuk menghasilkan gelombang suara saat kita memasukkan jari ke dalam kuvet dan bersinar dari Pulsa dari cahaya laser dekat-IR 650nm. Jika terjadi absorpsi pada jaringan manusia yang tereksitasi pada panjang gelombang yang diserap oleh molekul maka absorpsi glukosa akan menyebabkan pemanasan lokal. Peningkatan suhu menyebabkan ekspansi termal yang cepat, yang menghasilkan gelombang tekanan

3. Transduser audio yang mengubah gelombang akustik yang dihasilkan oleh laser berdenyut yang 
Analisa Keakuratan Kadar Glukosa Darah Menggunakan Clarke-Error Grid Analisis pada Alat Ukur Non-invasive menggunakan Sensor Photoacoustic

berinteraksi dengan jaringan menjadi sinyal listrik.

4. Penguat operasi: OP AMP LM741 adalah penguat operasional (penguat pada sebuah chip). Meskipun sebagian besar desain mutakhir mengalahkannya dalam hal kecepatan, kebisingan rendah, dll. Alat ini masih berfungsi dengan baik sebagai perangkat serbaguna. Salah satu keuntungannya adalah bahwa itu dikompensasikan (respon frekuensinya disesuaikan) untuk memastikan bahwa dalam banyak keadaan itu tidak akan menghasilkan osilasi palsu yang tidak diinginkan.

5. Papan mikrokontroller yang berbasis ATmega 328 yang terdiri dari 14 pin input dan output digital, 6 pin input sebagai pin input analog dan 6 pin output Pulse width Modulation (PWM), resonator keramik $16 \mathrm{MHz}$ dan koneksi USB yang dapat dihubungkan ke komputer. Arduino Uno R3 pengembangan dengan menambahkan pin SDA dan SCL. Perangkat lunak arduino menggunakan kemampuan yang dapat mengunggah dengan menekan tombol unggah pada ardiuno itu sendiri dan diprogram menggunakan perangkat lunak arduino.

6. Layar LCD terdiri dari dua baris dengan 16 karakter yang masing-masing karakter terdiri dari $(5 \times$ 8 atau $5 \times 11$ dot matrix). Kontras tampilan tergantung pada tegangan catu daya apakah pesan ditampilkan dalam satu atau dua baris. Untuk alasan ini, tegangan 0-5volt yang bervariasi diterapkan pada pin bertanda Vee. Dalam proyek ini, Vee telah disetel ke nol.

7. Analisis; Menggunakan Clarke Error Grid Analysis (EGA) untuk menganalisa keakuratan hasil pengukuran klinis pasien terutama kadar glukosa darah dengan membandingkan alat ukur yang dihasilkan dengan non-invasive dan nilai referensi dengan invasive. Clarke EGA dikembangkan dari tahun 1970 dan dijelaskan secara detail pada diabetes care pada tahun 1987 sehingga sebagai salah satu gold standar dalam menentukan akurasi pengukuran glukosa darah. Clarke EGA dibagi dengan lima zona A, B, C, D dan E dengan menggunakan Beckman Analysis, dimana Zona A dan $\mathrm{B}$ adalah nilai glukosa yang akurat yang dapat diterima, Zona $\mathrm{C}$ nilai glukosa yang membutuhkan koreksi agar tidak menjadi hasil yang buruk, Zona D nilai yang dideteksi menyimpang dan dapat diperbaiki dan Zona E, nilai kadar glukosa yang salah.

Pengembangan alat ukur ini untuk Blood cholesterol and Glucose Monitoring (BCGM) menggunakan optik sensor dengan LED IR. Metode pengembangan BCGM dengan langkah - langkah sebagai berikut:

1. Desain instrument BCGM: mendesain dan membuat finger sensor IR Laser dan photodiode, Membuat rangkaian amplifier penguat tegangan menggunakan LM358N dan menghubungkan ke mikrokontroller Arduino.

2. Prosessing: Tegangan ouput sensor dan mengukur total kadar kolesterol dan glukosa dalam darah invasive menggunakan MMS Autocheck pada waktu yang sama dari partisipan pria dan wanita usia 20 - 60 tahun pada 40 partisipan. Data tegangan output sensor untuk glukosa darah dalam waktu 10 detik dan kolesterol darah 20 detik dan masing masing pengambilan data sebanyak 5 
kali. Tegangan output finger sensor dikorelasikan dengan total glukosa dalam darah dengan matematika untuk mendapatkan persamaan linear atau polynominal sebagai formulasi dalam algoritma program untuk mengkalisifikasi nilai glukosa dalam darah yang diprosess oleh mikrokontroller dan ditampilkan pada monitor.

3. Validasi: Hasil pengukuran divalidasi dengan membandingkan alat ukur invasive Autochek dengan melakukan pengukuran pada partisipan pria dan wanita usia 20 - 60 tahun pada lebih dari 50 partisipan. Menggunaka Clarke Error Grid Analysis (EGA) untuk menganalisa keakuratan hasil pengukuran klinis pasien terutama kadar glukosa darah dengan membandingkan alat ukur yang dihasilkan dengan non-invasive dan nilai referensi dengan invasive.

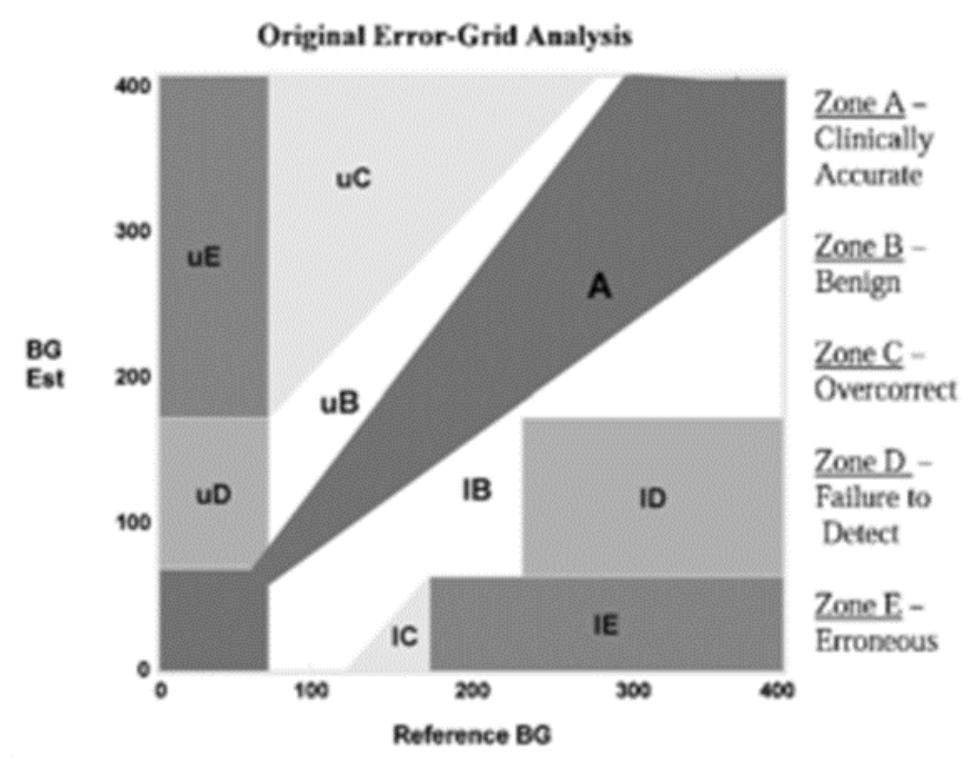

Gambar 2. Orginal Clarke EGA untuk glukosa Darah

\section{HASIL DAN PEMBAHASAN}

\section{A. Hasil Penelitian}

Hasil pengambilan data dengan melakukan pengukuran menggunakan teknik invasive dan non-invasive menggunakan sensor photoacoustic. Perbedaan tegangan output sensor terlihat, disebabkan oleh penyerapan cahaya di jaringan tubuh dan refleksi cahaya yang berbeda. Kadar glukosa darah setiap orang dipengaruhi perbedaan ini, seperti pada tabel berikut:

Tabel 1. Data Pengukuran kadar glukasa darah dan tegangan output sensor

\begin{tabular}{ccc}
\hline Sampel & Tegangan (Volt) & Glukosa (mg/dl) \\
\hline A & 1.339 & 97 \\
\hline B & 1.388 & 102 \\
\hline C & 1.466 & 112 \\
\hline D & 1.364 & 119 \\
\hline E & 1.39 & 121 \\
\hline F & 1.544 & 126 \\
\hline G & 1.564 & 137 \\
\hline H & 1.57 & 166 \\
\hline I & 1.696 & 169
\end{tabular}


Analisa Keakuratan Kadar Glukosa Darah Menggunakan Clarke-Error Grid Analisis pada Alat Ukur Non-invasive menggunakan Sensor Photoacoustic

(Usman Umar, Risnawaty Alyah, Imran Amin)

\begin{tabular}{ccc}
\hline & & \\
\hline Sampel & Tegangan (Volt) & Glukosa (mg/dl) \\
\hline $\mathbf{J}$ & 1.711 & 176 \\
\hline $\mathbf{K}$ & 1.713 & 186 \\
\hline $\mathbf{L}$ & 1.887 & 219 \\
\hline
\end{tabular}

Pada Tabel 1 diperoleh dua jenis data yaitu nilai kadar gula darah $(\mathrm{mg} / \mathrm{dl})$ dan nilai tegangan output sensor (V). Kedua data tersebut diolah sehingga diperoleh korelasi sederhana dari nilai kadar glukosa darah dan tegangan output sensor dengan melakukan regresi polynomial sehingga diperoleh persamaan $\mathrm{Y}=613,68 \mathrm{x} 3+3079.2 \mathrm{x} 2-4891 \mathrm{x}+2607.2$, dengan koefisien korelasi regresi $\mathrm{R} 2=$ 0,9234 . Tegangan output sensor belum linier terhadap nilai kadar glukosa darah yang diukur dengan teknik invasif, yang disebabkan oleh beberapa faktor seperti pemasangan sensor yang tidak konsisten, kemungkinan cahaya lain yang diterima oleh fotodioda sehingga pantulan cahaya tidak murni dan ketebalan kulit mempengaruhi penyerapan cahaya pada jaringan jari.

Persamaan regresi polynomial tersebut nilai R2 sudah mendekati 1 namun untuk memudahkan mengkonversi nilai tegangan sensor ke glukosa pada program mikrokontroller lebih mudah. Penentuan nilai glukosa darah dengan mudah dilakukan dengan membuat regresi linear, untuk mendapatkan persamaan yang simple dengan nilai regresi square (R2) mendekati satu, diperoleh persamaan $\mathrm{Y}=$ 212.02(x) - 185.04, dengan koefisien korelasi regresi $\mathrm{R} 2=0.9132$. Persamaan ini berfungsi untuk merancang program pada mikrokontroler

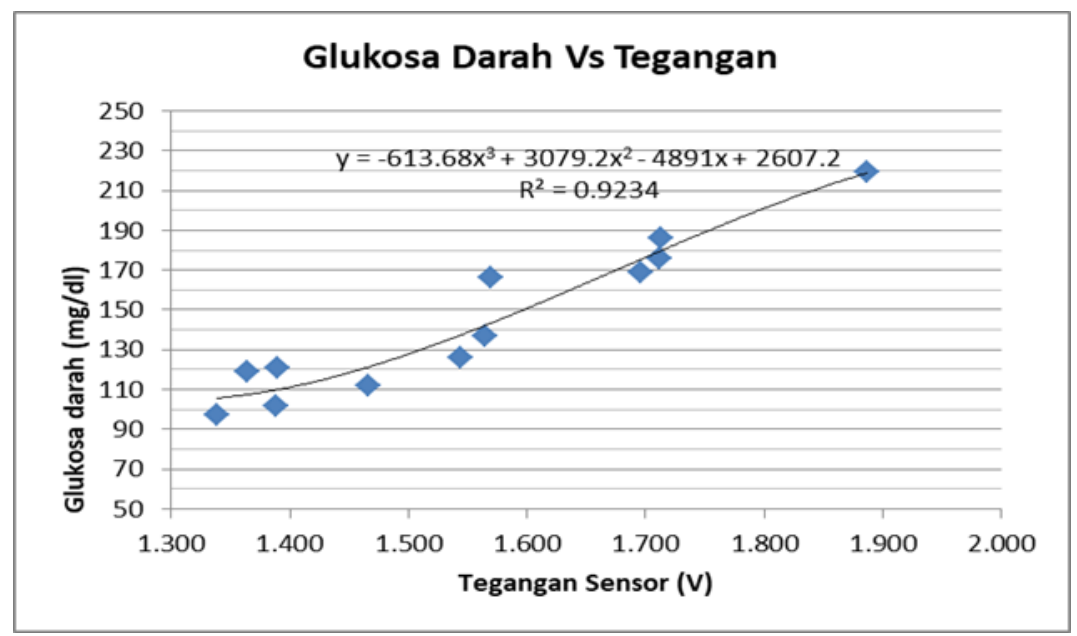

Gambar 3. Grafik persamaan Polynomial

Data yang ada tersebut menunjukan bahwa tegangan dengan kadar glukosa darah linear, sehingga dapat diperoleh nilai akurasi yang baik. Peningkatan kinerja diperlukan untuk menjaga stabilitas tegangan input dengan penambahan stabilizer tegangan.

Eksperimen selanjutnya dengan perbandingan data alat pengukur kadar glukosa invasif dengan alat pengukur non-invasif yang telah didesain. Data dari alat pengukur kadar glukosa darah teknik invasif sangat akurat karena menggunakan sampel darah, tetapi data dari alat pengukur kadar glukosa darah teknik non-invasif tergantung pada deteksi sensor NIR. Beberapa contoh telah diambil untuk menguji konsep tersebut. Pengujian alat dengan melakukan validasi dengan metode, mengukur 
kadar glukosa darah dengan teknik invasive, dan diukur kembali dengan teknik non invasive. Sistem sirkuit dirancang dan diuji terhadap 15 relawan dalam rentang usia (20-44); hasil ditunjukkan pada tabel 2 bahwa pengukuran konsentrasi glukosa oleh sirkuit yang telah dirancang kemudian dibandingkan dengan metode non-invasif dan Invasif.

Tabel 2. Hasil akhir untuk mengukur konsentrasi glukosa oleh Invasive dan Noninvasive method

\begin{tabular}{ccc}
\hline Partisipan & Invasive (Autocheck) $\mathrm{mg} / \mathrm{dl}$ & Non-Invasive (IR/PA) mg/dl \\
\hline A & 67 & 69 \\
\hline $\mathbf{B}$ & 71 & 72 \\
\hline $\mathbf{C}$ & 77 & 76 \\
\hline $\mathbf{D}$ & 82 & 78 \\
\hline $\mathbf{E}$ & 89 & 82 \\
\hline $\mathbf{F}$ & 98 & 96 \\
\hline $\mathbf{G}$ & 100 & 102 \\
\hline $\mathbf{H}$ & 117 & 126 \\
\hline $\mathbf{I}$ & 122 & 128 \\
\hline $\mathbf{J}$ & 137 & 130 \\
\hline $\mathbf{K}$ & 143 & 148 \\
\hline $\mathbf{L}$ & 169 & 160 \\
\hline $\mathbf{M}$ & 176 & 181 \\
\hline $\mathbf{N}$ & 186 & 178 \\
\hline $\mathbf{O}$ & 219 & 226 \\
\hline $\mathbf{P}$ & 268 & 278 \\
\hline
\end{tabular}

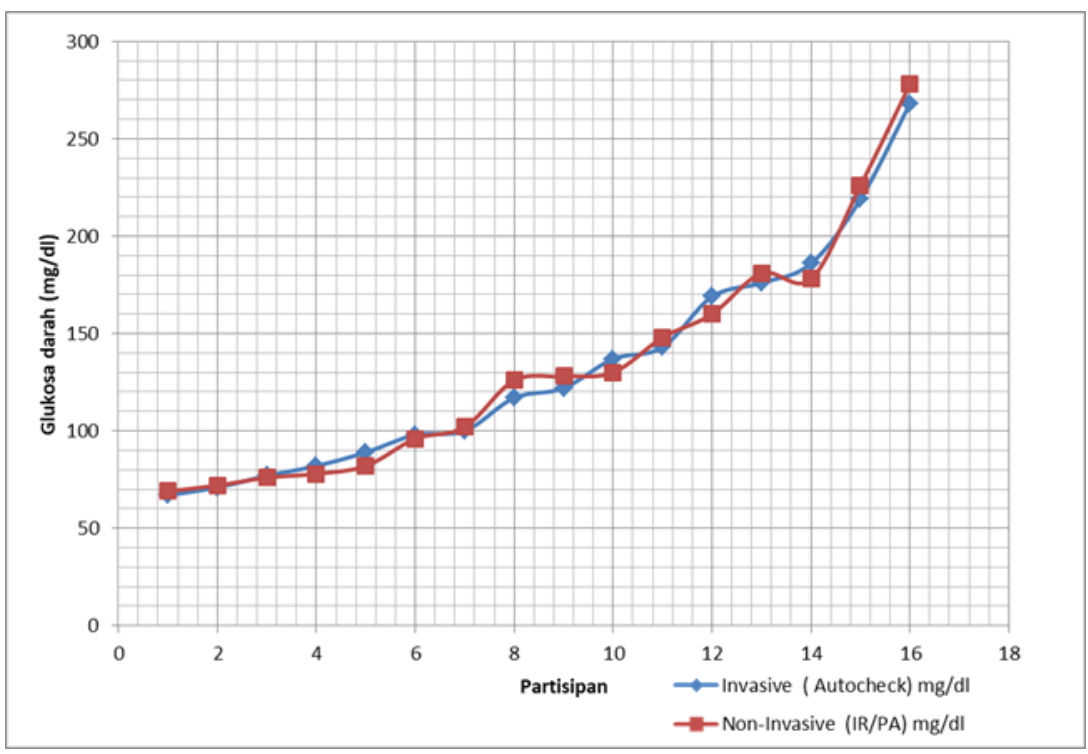

Gambar 4. Grafik pengukuran Invasif dan non-invasive glukosa darah. 


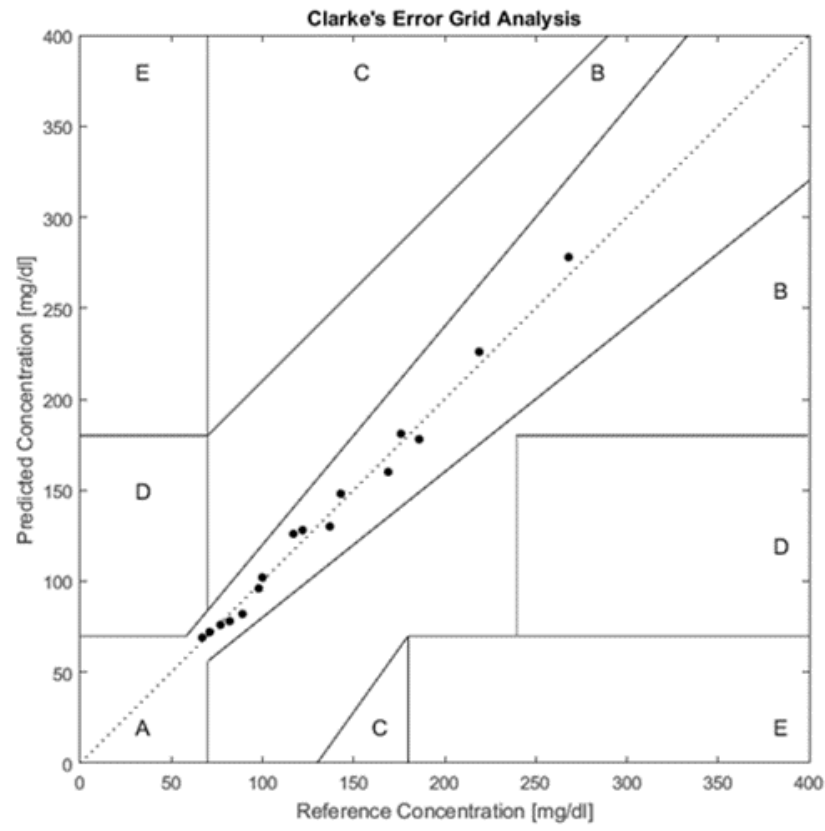

Gambar 5. Hasil analisa Clarke -EGA hasil pengukuran Invasif dan non-invasive menggunakan sensor Photoacoustik

Dari Tabel 2, dan grafik terlihat bahwa perbedaan data antara kedua perangkat masih ada dengan perbedaan 1 hingga 9, dengan nilai error 1\% sampai dengan $8 \%$. Sebagai data standar adalah nilai pengukuran dari teknik invasive sebagai nilai referensi, hasil pengukuran teknik invasive sebagai dasar pembanding dengan nilai teknik non-invasive untuk mengvalidasi alat ukur yang telah didesain. Nilai toleransi ini menunjukkan akurasi yang baik, dan masih perlu perbaikan terus menerus. Setelah dilakukan uji regresi statistik, diperoleh hasil regresi square (R2) menunjukkan nilai 0,9846, dan standar error 6,02, Hasil pengukuran dengan kondisi data tidak merata, menyebabkan nilai varians tinggi, semakin tinggi fluktuasi data dengan data lainnya dengan adanya data bernilai tinggi dan data bernilai rendah dari hasil pengukuran dari teknik invasive. Pada subjek $\mathrm{B}$ dan $\mathrm{C}$, data dengan nilai terkecil menunjukkan hasil yang relatif sama antara pengukuran invasif dan non-invasif; akurasi pengukuran non-invasif cukup baik. Subjek H dan L menunjukkan bahwa hasil pengukuran noninvasif masih lebih tinggi dibanding dengan nilai pengukuran invasive, sehinggan nilai error juga tinggi yaitu 5\% sampai dengan $8 \%$.

\section{B. Pembahasan}

Analisa data hasil pengukuran dengan invasive sebagai nilai referensi (y) dan pengukuran non-invasive menggunakan sensor Photoacoustic sebagai nilai prediksi (yp), dengan menggunakan Clarke Error Grid Analisis (EGA) bahwa yang masuk dalam zona A dan B, Zona A (dapat diterima) merupakan nilai glukosa yang menyimpang dari nilai referensi sebesar $\pm 20 \%$ atau berada dalam kisaran hipoglikemik ( $<70 \mathrm{mg} / \mathrm{dl}$ ), dan referensi juga berada dalam kisaran hipoglikemik. Nilai dalam 
kisaran ini tepat secara klinis dan dengan demikian dicirikan oleh perawatan klinis yang benar. Zona B (kesalahan jinak) terletak di atas dan di bawah zona A. Dari hasil analisa bahwa semua pengukuran masuk dalam Zona A sehingga alat dengan sensor photoacosutic dapat diterima sebagai alat pembanding alat ukur invasive.

Dengan sensor foto-akustik pada panjang gelombang mulai dari $1000 \mathrm{~nm}$ hingga $1200 \mathrm{~nm}$ penyerapan terjadi dan lebih efektif pada panjang gelombang $900 \mathrm{~nm}$ sesuai dengan sensor yang digunakan. Walaupun glukosa mempunyai daya serap yang lebih rendah di sekitar panjang gelombang tersebut, karena tidak dipengaruhi oleh atenuasi minimum sinyal optik komponen lain, kedalaman penetrasi yang diinginkan tercapai dengan energi substansial yang tersedia untuk penyerapan oleh glukosa.

Faktor-faktor yang mempengaruhi hasil pengukuran tidak terdistribusi secara merata pada teknik non-invasif seperti; pemasangan sensor jari tidak konsisten; sensor tidak cukup kuat untuk menjepit jari, kemungkinan cahaya lain masuk dan ditangkap oleh fotodioda dan ketebalan jari juga dapat mempengaruhi hasil deteksi sensor.

\section{KESIMPULAN}

Hasil penelitian yang disajikan merupakan pengukuran data hasil pengukuran glukosa darah menggunakan teknik non-invasif yang telah dibuat dengan menggunakan sensor foto-akustik yang terdiri dari emitor infrared dan detektor Photodiode. Hasil pengukuran dibandingkan dengan pengukuran dengan prosedur teknik invasif. Analisa Clarke EGA ditunjukkan pada semua hasil pengukuran masuk dalam Zona A yang dapat diterima. Hasil pengembangan alat ini adalah inovasi alternatif yang dapat digunakan untuk mengukur glukosa darah, yang mudah digunakan dan tidak menyakitkan serta biaya rendah karena tidak menggunakan strip untuk media sampel darah. Keakuratan instrumen berkembang cukup baik dan dapat diandalkan.

\section{UCAPAN TERIMA KASIH}

Terima kasih kepada Politeknik Kesehatan Muhammadiya Makassar dan semua teman sejawat yang telah membantu yang telah memberikan dukungan untuk mengembangkan alat ini sehingga dapat kami laksanakan dengan menghasilkan purwa rupa alat pemantau kadar glukosa darah noninvasive.

\section{DAFTAR PUSTAKA}

Ascaso, F. J. (2016). Noninvasive Continuous Monitoring of Tear. Optometry \& Vision Science, 93(4), 426-434. https://doi.org/10.1097/OPX.0000000000000698

Chen, C., Zhao, X. L., Li, Z. H., Zhu, Z. G., Qian, S. H., \& Flewitt, A. J. (2017). Current and emerging technology for continuous glucose monitoring. Sensors (Switzerland), 17(1), 1-19. https://doi.org/10.3390/s17010182 
Cherkasova, O., Nazarov, M., \& Shkurinov, A. (2016). Noninvasive blood glucose monitoring in the terahertz frequency range. Optical and Quantum Electronics, 48(3), 1-12. https://doi.org/10.1007/s11082-016-0490-5

Choi, H., Naylon, J., Luzio, S., Beutler, J., Birchall, J., Martin, C., \& Porch, A. (2015). Design and in Vitro Interference Test of Microwave Noninvasive Blood Glucose Monitoring Sensor. IEEE Transactions on Microwave Theory and Techniques, 63(10), 3016-3025. https://doi.org/10.1109/TMTT.2015.2472019

Geng, N. (2017). Synthesis of Polyproline Spacers between NIR Dye Pairs for FRET to Enhance Photoacoustic Imaging.

Haryati, S. (2012). Research and Development (R\&D) Sebagai Salah Satu Model Penelitian dalam Bidang Pendidikan. Research And Development (R\&D) Sebagai Salah Satu Model Penelitian Dalam Bidang Pendidikan, 37(1), 11-26.

Haxha, S., \& Jhoja, J. (2016). Optical Based Noninvasive Glucose Monitoring Sensor Prototype. IEEE Photonics Journal, 8(6). https://doi.org/10.1109/JPHOT.2016.2616491

International Diabetes Federation. (2017). Diabetes Voice. Www.Diabetesvoice.Org, 62(1). https://doi.org/10.1001/jama.298.12.1472

Kemenkes. (2016). Profil Kesehatan Indonesia 2016. In Profil Kesehatan Provinsi Bali. Retrieved from http://www.depkes.go.id/resources/download/pusdatin/profil-kesehatan-indonesia/ProfilKesehatan-Indonesia-2016.pdf

Riley, L., Guthold, R., Cowan, M., Savin, S., Bhatti, L., Armstrong, T., \& Bonita, R. (2016). The world health organization STEPwise approach to noncommunicable disease risk-factor surveillance: Methods, challenges, and opportunities. American Journal of Public Health, 106(1), 74-78. https://doi.org/10.2105/AJPH.2015.302962

WHO. (2016). Global report on diabetes. Isbn, 978, 92-94. Retrieved from http://www.who.int/about/licensing/copyright_form/index.html\%0Ahttp://www.who.int/about /licensing/

W. L. Clarke, “The Original Clarke Error Grid Analysis (EGA)," Diabetes Technol. Ther., vol. 7, no. 5, hal. 776-779, 2005. 